\title{
Macromolecular composition of terrestrial and marine organic matter in sediments across the East Siberian Arctic Shelf
}

\author{
Robert B. Sparkes ${ }^{1,2}$, Ayça Doğrul Selver ${ }^{1,3}$, Örjan Gustafsson ${ }^{4}$, Igor P. Semiletov ${ }^{5,6,7}$, Negar Haghipour ${ }^{8}$, \\ Lukas Wacker ${ }^{9}$, Timothy I. Eglinton ${ }^{8}$, Helen M. Talbot ${ }^{10}$, and Bart E. van Dongen ${ }^{1}$ \\ ${ }^{1}$ School of Earth and Environmental Sciences and Williamson Research Centre for Molecular Environmental Science, \\ University of Manchester, Manchester, UK \\ ${ }^{2}$ School of Science and the Environment, Manchester Metropolitan University, Manchester, UK \\ ${ }^{3}$ Balıkesir University, Geological Engineering Department, Balıkesir, Turkey \\ ${ }^{4}$ Department of Environmental Science and Analytical Chemistry (ACES) and the Bolin Centre for Climate Research, \\ Stockholm University, Stockholm, Sweden \\ ${ }^{5}$ Pacific Oceanological Institute Far Eastern Branch of the Russian Academy of Sciences, Vladivostok, Russia \\ ${ }^{6}$ International Arctic Research Center, University of Alaska, Fairbanks, USA \\ ${ }^{7}$ National Tomsk Research Polytechnic University, Tomsk, Russia \\ ${ }^{8}$ Geological Institute, ETH Zurich, Zurich, Switzerland \\ ${ }^{9}$ Laboratory of Ion Beam Physics, ETH Zurich, Zurich, Switzerland \\ ${ }^{10}$ School of Civil Engineering and Geosciences, Newcastle University, Newcastle, UK
}

Correspondence to: Robert B. Sparkes (r.sparkes@mmu.ac.uk)

Received: 6 June 2016 - Published in The Cryosphere Discuss.: 13 June 2016

Revised: 23 September 2016 - Accepted: 4 October 2016 - Published: 24 October 2016

\begin{abstract}
Mobilisation of terrestrial organic carbon (terrOC) from permafrost environments in eastern Siberia has the potential to deliver significant amounts of carbon to the Arctic Ocean, via both fluvial and coastal erosion. Eroded terrOC can be degraded during offshore transport or deposited across the wide East Siberian Arctic Shelf (ESAS). Most studies of terrOC on the ESAS have concentrated on solventextractable organic matter, but this represents only a small proportion of the total terrOC load. In this study we have used pyrolysis-gas chromatography-mass spectrometry (pyGCMS) to study all major groups of macromolecular components of the terrOC; this is the first time that this technique has been applied to the ESAS. This has shown that there is a strong offshore trend from terrestrial phenols, aromatics and cyclopentenones to marine pyridines. There is good agreement between proportion phenols measured using py-GCMS and independent quantification of lignin phenol concentrations $\left(r^{2}=0.67, p<0.01, n=24\right)$. Furfurals, thought to represent carbohydrates, show no offshore trend and are likely found in both marine and terrestrial organic matter. We have also collected new radiocarbon data for bulk
\end{abstract}

OC $\left({ }^{14} \mathrm{C}_{\mathrm{OC}}\right)$ which, when coupled with previous measurements, allows us to produce the most comprehensive ${ }^{14} \mathrm{C}_{\mathrm{OC}}$ map of the ESAS to date. Combining the ${ }^{14} \mathrm{C}_{\mathrm{OC}}$ and pyGCMS data suggests that the aromatics group of compounds is likely sourced from old, aged terrOC, in contrast to the phenols group, which is likely sourced from modern woody material. We propose that an index of the relative proportions of phenols and pyridines can be used as a novel terrestrial vs. marine proxy measurement for macromolecular organic matter. Principal component analysis found that various terrestrial vs. marine proxies show different patterns across the ESAS, and it shows that multiple river-ocean transects of surface sediments transition from river-dominated to coastalerosion-dominated to marine-dominated signatures.

\section{Introduction}

Northern Hemisphere permafrost is a significant and vulnerable store of organic carbon (OC), containing approximately $40 \%$ of the global soil OC budget (Northern Hemi- 
sphere terrestrial permafrost contains at least $1330-1580 \mathrm{Gt}$ OC, other biomes contain $2050 \mathrm{Gt}$ OC; Schuur et al., 2015). The vast amount of soil OC currently freeze-locked in the permafrost is vulnerable to global warming and can be remobilised through permafrost thawing, increased river runoff and coastal erosion (Stendel and Christensen, 2002; Vonk et al., 2010, 2015). Recent studies show that the Arctic region is warming twice as fast as other parts of the world (IPCC, 2013) and that both the flux and nature of remobilised terrestrial organic carbon (terrOC) are projected to change in the coming decades (Holmes et al., 2002, 2012; van Dongen et al., 2008a; O'Donnell et al., 2014). Indeed, in parts of the Eurasian Arctic region, global warming caused an increase in permafrost temperatures of up to $2{ }^{\circ} \mathrm{C}$ between 1971 and 2010 (Schuur et al., 2008) and up to $7 \%$ increase in discharge rates of the main Eurasian rivers (Peterson et al., 2002). Coupled warming and increased discharge are releasing "old" carbon from thawing permafrost, previously stored for thousands of years (Gustafsson et al., 2011; Feng et al., 2013, 2015b; Vonk et al., 2012), via active layer deepening and thermokast erosion events (Vonk and Gustafsson, 2013; IPCC, 2013). Additionally, coastal erosion is an important process through which vast amounts of terrOC are transported to the Arctic shelf (Ping et al., 2011; Vonk et al., 2012). In particular, the eastern Siberian coastline is dominated by ice complex deposits (ICDs; also known as "Yedoma"). These are Plio-Pleistocene permafrost deposits rich in OC, deposited in steppe-tundra environments (Lantuit et al., 2013; Schirrmeister et al., 2008, 2011; Strauss et al., 2012, 2013; Vonk et al., 2010, 2012). Coastal erosion transports $44 \pm 10 \mathrm{Mt}$ of terrOC to the East Siberian Arctic Shelf (ESAS) annually (Vonk et al., 2012). This amount will likely increase in the next decades due to diminishing sea ice cover resulting in increased storm frequency and wave fetch (Stein and MacDonald, 2004; Vonk et al., 2010).

The fate of terrOC in the Arctic region is still a matter of debate. Susceptibility to degradation will depend on the molecular composition of the terrOC being released, the chemical conditions present in the water column and surface sediments, and the physical characteristics of transport (time spent in water column, sediment transport style, turbidity). Stein and MacDonald (2004) assumed that degradation rates of terrestrial particulate organic carbon (POC) in coastal Arctic environments were comparable to the global average degradation rate of riverine POC. This suggests that a substantial amount of the terrOC is not degraded during transport across the Arctic shelves but is preserved in marine sediments or delivered to the deep ocean. However, recent studies suggested that a much greater proportion of the river-transported terrOC in this region is degraded in the water column, mainly close to the point of origin (Karlsson et al., 2011; Sánchez-García et al., 2011; Semiletov et al., 2007, 2012; Tesi et al., 2014, 2016; van Dongen et al., 2008b; Vonk et al., 2012). The study by van Dongen et al. (2008b), for instance, showed that $65 \%$ of terrestrial POC transported by the sub-Arctic Kalix River is degraded in the inner lowsalinity zone (within $60 \mathrm{~km}$ of the river). Ice complex material has also been shown to be labile upon its remobilisation (Tesi et al., 2016; Vonk et al., 2013a, b; Zimov et al., 2006). Tesi et al. (2016) showed that different components of the carbon load, in both fluvial and coastal erosion sediments, will deposit and degrade at different rates, and therefore terrOC can be considered to exhibit non-uniform behaviour. Density and particle size separations found that OC in topsoil and ICD sediments was distributed between large low-density particles of plant matter and high-density fine particles $(<38 \mu \mathrm{m})$. However, the large low-density particles were rapidly deposited in nearshore sediments and in the distal ESAS the OC was predominantly found in the fine and ultrafine high-density particles, suggesting the presence of mineral-OC complexes. They showed that some biomarker molecules could exhibit up to $98 \%$ degradation across the shelf and produced average degradation rates of up to $90 \%$ for OC in topsoil and $60 \%$ for OC from ice complexes. This indicated that that patterns seen off the ESAS are a combination of hydrodynamic sorting of OC-bearing particles and degradation of terrOC during cross-shelf transport. Overall, these studies of terrOC transport and degradation suggest that the degradation extent used by Stein and MacDonald (2004) is likely an underestimate and that a much greater proportion of the remobilised terrOC will be degraded and released into the atmosphere as greenhouse gases than previously thought. This will lead to a positive feedback with global climate warming, with the greenhouse gas release translocated from the point of original thaw (Anderson et al., 2009; Alling et al., 2010; Sánchez-García et al., 2011; Vonk and Gustafsson, 2013; IPCC, 2013). Furthermore, before being vented from the surface ocean as $\mathrm{CO}_{2}$, this degraded terrOC will cause severe ocean acidification of the ESAS (Semiletov et al., 2016).

Previous studies looking into the composition and fate of terrOC transported to the Arctic shelf primarily focused on the extractable fraction of the terrOC (that which can be isolated using a combination of organic solvents; Belicka and Harvey, 2009; Bischoff et al., 2016; Doğrul Selver et al., 2012, 2015; Drenzek et al., 2007; Fernandes and Sicre, 2000; Gustafsson et al., 2011; Karlsson et al., 2011; SánchezGarcía et al., 2014; Sparkes et al., 2015; van Dongen et al., 2008b, a; Vonk et al., 2010, 2012; Yunker et al., 1995). Much less is known about the non-extractable portion. This nonextractable OC constitutes the largest proportion of bulk OC transported to the Arctic Ocean and contains macromolecular components such as lignin, proteins and cellulose, as well as the degradation products of these. Only a few studies have analysed macromolecular terrOC transported to the Eurasian Arctic shelves, and they have only sampled a small fraction of the shelf area (Feng et al., 2013; Guo et al., 2004; Peulvé et al., 1996; Tesi et al., 2014; Winterfeld et al., 2015). Guo et al. (2004), for instance, analysed the macromolecular OC compositions of great Russian Arctic rivers (GRARs) estu- 
ary surface sediments using pyrolysis-gas chromatographymass spectrometry (py-GCMS). Based on the increasing relative abundance of carbohydrate moieties towards eastern Siberia, they suggested that terrOC transported to the Arctic Ocean via the eastern GRARs (from estuaries dominated by continues permafrost) was less degraded than OC transported by the western GRARs (from estuaries no longer dominated by continues permafrost). Feng et al. (2013) showed, by analysing the radiocarbon age of specific lignin moieties in the same set of GRAR sediments, that the vascular-plantderived lignin phenols may have originated from young surface soils but that wax lipids mainly originated from deeper permafrost horizons, implying that climate warming may cause old permafrost carbon remobilisation. Recent work investigating macromolecular moieties across the Arctic found a large concentration of plant-derived compounds on the ESAS (Feng et al., 2015a, b), ascribed to enhanced preservation of these in the exceptionally cold climate, increased ICD input (Vonk et al., 2012) or a lack of marine and bedrockderived OC in the area (Semiletov et al., 2005).

It also remains poorly understood how macromolecular terrOC behaves after it is transported to the Arctic Ocean. Recent analyses on the ESAS indicate that lignin may degrade faster than wax lipids (Tesi et al., 2014), suggesting that macromolecular terrOC may also behave non-uniformly. However, lignin represents only one part of the macromolecular fraction of the remobilised terrOC, so it remains unclear to what extent these results are representative for the entire macromolecular fraction. Analysis by py-GCMS is a rapid method of investigating macromolecular OC (Guo et al., 2004, 2009; Xu et al., 2009). Flash heating in an oxygen-free atmosphere produces thermal breakdown products which are GC-amenable; however the thermal breakdown caused by the pyrolysis process can produce hundreds or thousands of different compounds, leading to complex ion chromatograms. This study uses a modified approach in which a small number of dominant compounds are used to represent groups of moieties (Guo et al., 2004, 2009). We aim to use this approach to better understand the origin and fate of macromolecular organic matter on the ESAS. We will demonstrate this innovative technique in the (relatively) wellconstrained Kolyma River outflow system, apply it to the entire ESAS and compare it to other macromolecular OC methods to demonstrate that py-GCMS is a rapid and robust procedure for macromolecular OC characterisation. We will then use py-GCMS to differentiate between various terrestrial and marine sources of OC in Arctic permafrost environments and to study, for the first time ever, their cross-shelf distributions.

\section{Method}

\subsection{Study area and sample collection}

Samples used in this study were collected from the East Siberian Arctic Shelf, a region extending from 130 to $175^{\circ} \mathrm{E}$ and from 70 to $77^{\circ} \mathrm{N}$, fed by four of the major GRARs (from west to east: Lena, Yana, Indigirka and Kolyma; see Fig. 1). Onshore, the East Siberian Arctic region consists largely of continuously permafrosted land. Enhanced climate warming in the next century is expected to increase the permeability of the permafrost layer (Feng et al., 2015b), leading to the mobilisation of OC from deeper, older permafrost horizons (Feng et al., 2013).

Water depth across the ESAS is $<100 \mathrm{~m}$ for several hundred kilometres, before dropping steeply at the shelf break. In addition to fluvial input, coastal erosion also plays an important role in sediment and OC delivery. Coastal erosion rates in the ESAS region are among the fastest in the Arctic, measuring up to $10 \mathrm{~m} \mathrm{yr}^{-1}$ (Lantuit et al., 2011; sections of particularly rapid coastal erosion are highlighted in Fig. 1). Erosion rates from ICDs are 5-7 times greater than other coastal permafrost and are responsible for a large proportion of the sediment and OC input to the ESAS (Vonk et al., 2012, and references therein). Biomarker investigations have been able to identify and model the contribution from fluvial and coastal delivery processes separately (Bischoff et al., 2016; Doğrul Selver et al., 2015; Sparkes et al., 2015). Tesi et al. (2016) showed that biomarker and radiocarbon values differed between areas dominated by ICDs (from coastal erosion) and topsoil (from river erosion), and that these values varied between size and density fractions. The annual OC delivery into this area is estimated to be $10 \mathrm{MtC} \mathrm{yr}^{-1}$ (Rachold et al., 2004), whilst Vonk et al. (2012) estimated $44 \mathrm{MtC} \mathrm{yr}^{-1}$ from ICDs. Karlsson et al. (2015) showed that, whilst terrOC was present across the ESAS, organic matter degradation in the eastern region, off the Kolyma River, was dominated by degrading marine OC, whilst in the western areas degradation was typically of terrOC.

Based on these findings, this study has sub-divided the ESAS into four smaller areas (see Fig. 1). The "nearshore Laptev Sea" zone (NLS) contains samples close to the eastern outflows of the Lena River delta. This includes the Buor-Khaya Bay between the Lena Delta and Cape BuorKhaya. Suspended material and surface sediments in this area are rich in terrOC (Charkin et al., 2011; Karlsson et al., 2011; Winterfeld et al., 2015), and glycerol dialkyl glycerol tetraether (GDGT) biomarkers are dominated by riverderived material (Sparkes et al., 2015), but there are also areas of rapid coastal erosion (Muostakh Island, Cape BuorKhaya) which deliver large amounts of sediment and OC to the bay. However, these coastal erosion sediments have noticeably different isotopic and biomarker signatures when compared to river sediments (Bischoff et al., 2016; Vonk et al., 2012). 


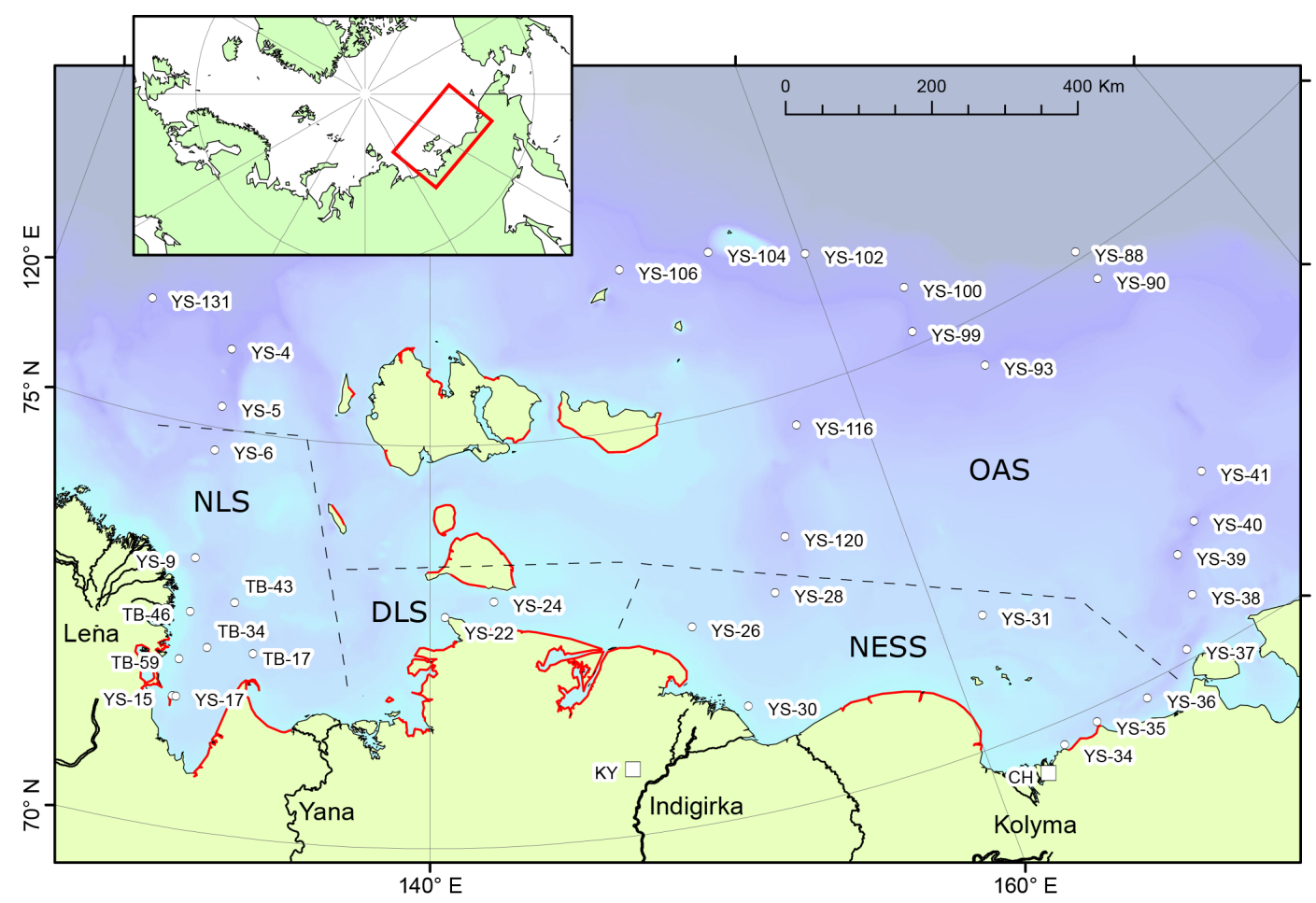

Figure 1. Map of the East Siberian Arctic Shelf (ESAS) showing the location of surface sediment samples (white circles) and ice complex samples (white squares) used in this study. Areas of rapid coastal erosion (> $1 \mathrm{~m} \mathrm{yr}^{-1}$; Lantuit et al., 2011) are shown in red. Regions of the ESAS referred to in the paper are shown using dashed lines (DLS: Dmitry Laptev Strait; NLS: nearshore Laptev Sea; NESS: nearshore East Siberian Sea; OAS: offshore Arctic shelf).

The "Dmitry Laptev Strait" zone (DLS), east of the NLS, is situated next to a rapidly eroding coastline (up to $10 \mathrm{~m} \mathrm{yr}^{-1}$; Lantuit et al., 2011) but is over $300 \mathrm{~km}$ from major river inputs. Bulk measurements $\left(\delta^{13} \mathrm{C}_{\mathrm{OC}}\right)$ and the branched and isoprenoid tetraether index (BIT, based on GDGTs) show a dominance of terrOC in this area (Sparkes et al., 2015; Vonk et al., 2012) - mainly due to a relatively low input of marine OC.

The "nearshore East Siberian Sea" (NESS) zone covers samples up to $200 \mathrm{~km}$ from the Indigirka and Kolyma River mouths. This region contains the terrOC-dominated section of the East Siberian Sea, as determined by Semiletov et al. (2005), and is affected by influx from the Indigirka and Kolyma rivers, as well as the Oyagosski Yar region of extensive coastal erosion to the west of the Indigirka and between the two rivers (Lantuit et al., 2011, Fig. 1). The Kolyma River outflow has been extensively studied as a terrestrialmarine transect (Doğrul Selver et al., 2015; Karlsson et al., 2015; Vonk et al., 2010). Bulk stable carbon isotopes and the bacteriohopanepolyol-based $R^{\prime}$ soil proxy (Doğrul Selver et al., 2012) showed linear trends offshore, but the BIT index decreased rapidly offshore, leading to a non-linear correlation between the terrestrial vs. marine proxies (Doğrul Selver et al., 2015). This has been explained by both varying contributions to the bulk OC signal from different OC sources
(Sparkes et al., 2015) and settling-fractionated sediment sorting (Tesi et al., 2016).

The "offshore Arctic shelf" (OAS) zone contains offshore sections of the Laptev and East Siberian seas, further than $200 \mathrm{~km}$ from the mouths of the great Russian Arctic rivers. Bulk isotopic measurements and terrestrial-marine biomarker proxies from this area all showed lower amounts of terrOC and a dominance of marine OC in this area (Bischoff et al., 2016; Doğrul Selver et al., 2015; Sparkes et al., 2015; Tesi et al., 2016; Vonk et al., 2012).

Thirty-six surface sediment samples from across the ESAS were used in this study (Fig. 1), along with six ICD samples from two terrestrial sample sites. The offshore surface sediments were collected during the International Siberian Shelf Study research cruise in 2008 (ISSS-08; Semiletov and Gustafsson, 2009) by a GEMAX dual gravity corer or a van Veen grab sampler. Sediment cores were sliced into $1 \mathrm{~cm}$ sections and transferred into pre-cleaned polyethylene containers; grab samples were sub-sampled using stainless steel instruments into pre-cleaned polyethylene containers. ICD samples were collected from the upper, middle and lower portions of river-bank profiles. All samples were kept frozen before stabilisation by freeze or oven drying $\left(50^{\circ} \mathrm{C}\right)$. The sample sediments used for py-GCMS analysis were previously solvent-extracted for biomarker analysis 
(Sparkes et al., 2015). Briefly, an ultrasonic extraction process using methanol, dichloromethane and $\mathrm{pH}$-buffered distilled water was used to remove extractable material, representing approximately $5 \%$ of the total OC content. The sample residues were dried and stored at room temperature prior to analysis in this study.

\section{$2.2{ }^{14} \mathrm{C}_{\mathrm{OC}}$ measurements}

In addition to existing radiocarbon data (Vonk et al., 2012), bulk radiocarbon measurements were carried out at the accelerator mass spectrometer (AMS) facility of the Laboratory of Ion Beam Physics (LIP) of the Swiss Federal Institute of Technology (ETH Zurich, Switzerland). Samples were fumigated in $8 \times 8 \times 15 \mathrm{~mm}$ silver boats (Elemental) with $\mathrm{HCl}>37 \%$ under vacuum in a desiccator (Komada et al., 2008), followed by neutralisation for at least $24 \mathrm{~h}$ with $\mathrm{NaOH}$. Prior to elemental analysis (EA) combustion, the samples were wrapped in a tin boat $8 \times 8 \times 15 \mathrm{~mm}$ (Elemental). Samples were measured in gas form with an EA directly coupled to the AMS. Gas targets were measured using the MICADAS instrument at the AMS facility of LIP at ETH Zurich. Samples have been corrected against an in-house anthracite coal blank and oxalic acid II standard reference material (NIST SRM 4990C).

\subsection{Pyrolysis-gas chromatography-mass spectrometry}

Dried solvent-extracted residues were analysed using pyGCMS. All samples were analysed using an Agilent GCMSD system interfaced to a CDS-5200 Pyroprobe. Briefly, $10-15 \mathrm{mg}$ of sediment was placed into a clean fire-polished quartz tube along with a known amount of internal standard ( $5 \alpha$-androstane) and pyrolysed at $700^{\circ} \mathrm{C}$ for $20 \mathrm{~s}$ in a flow of helium. The resulting material was transferred via a heated transfer line to an Agilent 7980A GC fitted with an Agilent HP-5 column coupled to an Agilent 5975 MSD single quadrupole mass spectrometer in electron ionisation mode (scanning a range of $\mathrm{m} / \mathrm{z} 50$ to 650 at $2.7 \mathrm{scans} \mathrm{s}^{-1}$; ionisation energy: $70 \mathrm{eV}$ ). The pyrolysis transfer line and rotor oven temperatures were set at $325^{\circ} \mathrm{C}$, the heated GC interface at $280^{\circ} \mathrm{C}$, the EI source at $230^{\circ} \mathrm{C}$ and the MS quadrupole at $150^{\circ} \mathrm{C}$. Helium was used as the carrier gas, and the samples were introduced in split mode (split ratio: $20: 1$; constant flow of $20 \mathrm{mLmin}^{-1}$, gas saver mode active). The oven was programmed from $40^{\circ} \mathrm{C}$ (held for $5 \mathrm{~min}$ ) to $250{ }^{\circ} \mathrm{C}$ at $4{ }^{\circ} \mathrm{C} \mathrm{min}^{-1}$, before being heated to $300^{\circ} \mathrm{C}$ at $20^{\circ} \mathrm{C} \mathrm{min}^{-1}$ and held at this temperature for $1 \mathrm{~min}$, for a total run time of $61 \mathrm{~min}$ sample $^{-1}$. Each sample was run at least in triplicate.

\subsection{Typical macromolecular moieties used as representative compounds}

Py-GCMS produces complex chromatograms containing hundreds of compounds. Approximately 70 of the most abundant pyrolysis moieties were identified (Fig. S1 and Table S1). Compounds were identified by comparison of relative retention times and spectra to those reported in the NIST library. Given the complexity of the GCMS chromatograms (see Fig. S1), it was not possible to integrate individual compounds in total ion current mode due to significant overlap between ion peaks. Instead, single ion filtering was used to measure the peak area of each compound. The major ion of each compound was filtered and integrated. In line with the approach taken in Guo et al. (2009), a selection of nine representative moieties were chosen that represent key compound classes, many of which can be linked to particular groups of terrestrial or marine macromolecular materials. For example, phenol is a key component of lignin, so it can potentially be used as a proxy for the pyrolysis products of terrestrial plant material, although it is also found in other compounds including tannins. Pyridine, a nitrogen-containing aromatic compound, is likely sourced from proteins, which can be found in soils but will mostly come from marine primary productivity in offshore samples. Representative compounds and their inferred sources can be found in Table 1. These compounds are identical to those analysed by Guo et al. (2009) except for the addition of pyridine and methyl pyridine in the "pyridines" group for the present study. Following the "abundance index" approach of Guo et al. $(2004,2009)$, the relative areas of the major ions in each group were compared to the total area of all measured compounds and are reported in Table S2. As discussed by Guo et al. (2004, 2009), this approach does not attempt to represent all organic compounds in the sediments, and the relative areas of major ions do not correspond to the actual abundance of each compound. However, this approach uses the most important compounds to demonstrate differences between sediment samples in a defined manner. Expanding on the work of Guo et al. (2004), this study includes samples from across the shelf, rather than just river mouths. Thus the E-W transect can be extended to a wholeshelf survey of macromolecular OC, and the spatial resolution increased.

\section{Results}

\subsection{Bulk radiocarbon composition}

Radiocarbon values ranged from -748 to $-313 \%$ (see Table S3). The most depleted values were in the Dmitry Laptev Strait, and the most enriched values were in the offshore Arctic shelf zone. The values from stations off the Indigirka River were more depleted than those off the Kolyma and Lena rivers. The range of $\Delta^{14} \mathrm{C}_{\mathrm{OC}}$ values is comparable to those measured by Vonk et al. (2012), and a comparison of the two datasets is shown in Fig. S3. 
Table 1. Representative moieties analysed in this study, and the compound groups that they are interpreted to represent (after Guo et al., 2004).

\begin{tabular}{llrl}
\hline $\begin{array}{l}\text { Compound } \\
\text { group }\end{array}$ & Compound & $\begin{array}{r}\text { Major ion } \\
M_{\mathrm{w}}\end{array}$ & Class \\
name & 94 & Lignin \\
\hline Phenols & Phenol & 79 & Marine N-rich \\
Pyridines & Pyridine & 93 & primary productivity \\
& Methyl pyridine & 106 & Anaerobic soils \\
Alkylbenzene & Dimethyl benzene & 96 & Less-degraded carbohydrates, \\
Furfurals & Furfural & 110 & both marine and terrestrial \\
& Methyl furfural & 116 & Mature OC \\
Aromatics & Indene & 128 & \\
& Napthalene & 96 & Soil polysaccharides \\
Cyclopentenones & Methylcyclopentenone & & \\
\hline
\end{tabular}
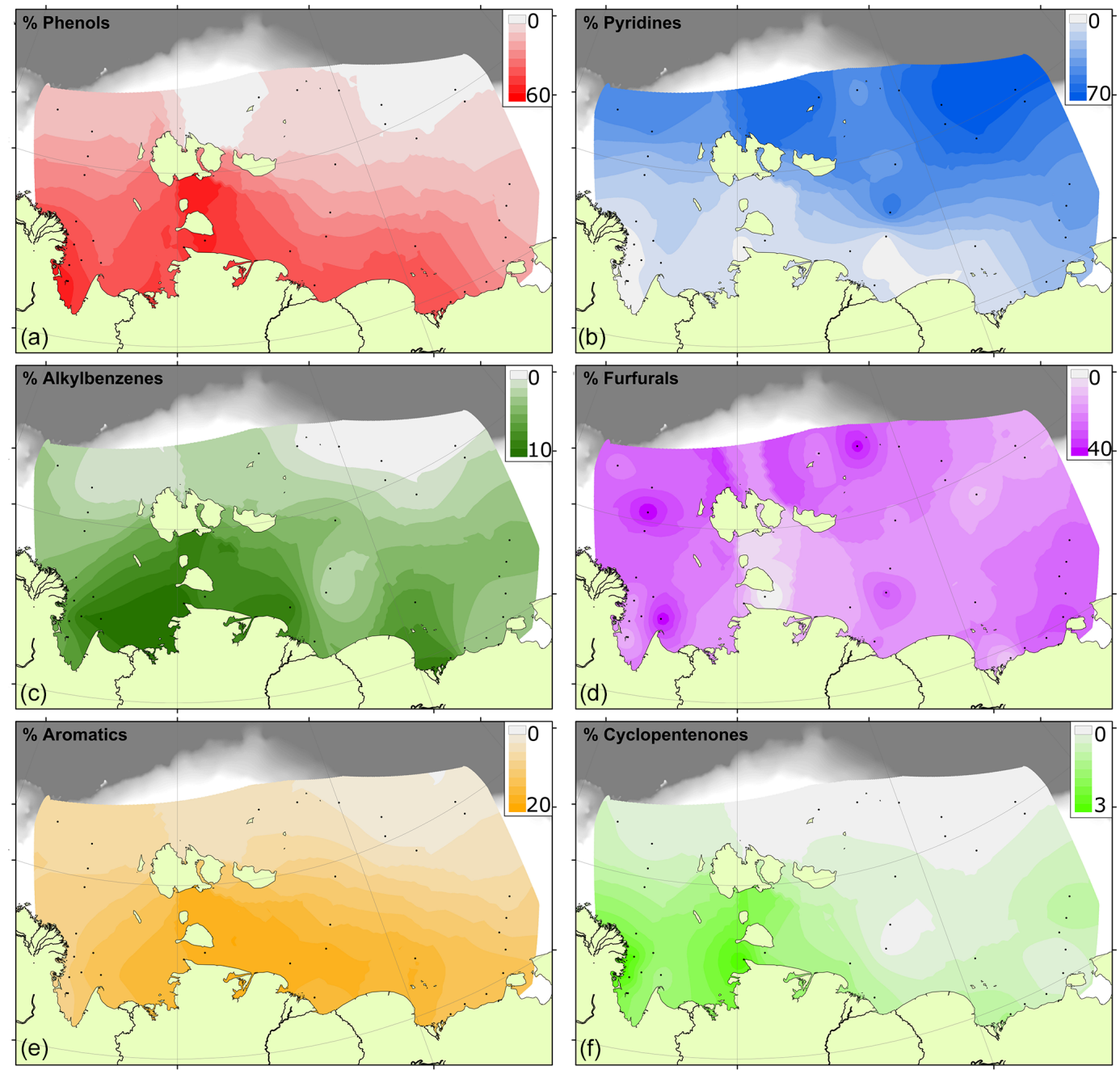

Figure 2. Distribution of (pyrolysis) compound classes across the ESAS. Distributions are reported as per cent of total, comparing the peak area of the major ion(s) in the compound class to the total peak area of major ions of all compound classes. See Table S2 for the breakdown of relative areas for each measured compound. Distributions are reported as a colour gradient from full colour (maximum observed) to white (zero). Sample locations are shown as black dots. Interpolation between sample sites was carried out using a "kriging" algorithm within the software package ArcGIS. 


\subsection{Distributions of individual py-GCMS markers across the ESAS}

Figure 2 shows the distribution of each compound group across the ESAS. The proportion of phenols ranged from 3 to $62 \%$ (Fig. 2a) with an average of $28 \pm 16 \%$ (1 SD). The value was highest in the nearshore Laptev Sea (average $42 \%$, $n=8$ ) and DLS (average $49 \%, n=2$ ), and lowest in the far offshore parts of the offshore Arctic shelf zone (YS-88 and YS-100, both $3 \%$ ). The proportion of pyridines ranged from 8 to $74 \%$ (Fig. 2b) with an average of $33 \pm 20 \%$ (1 SD). The value was highest in the far offshore samples, YS-88 $(74 \pm 5 \%)$ and YS-100 (69 $\pm 1 \%)$, whilst it is lowest in the nearshore Laptev Sea, at sample YS-15 (8 $\pm 2 \%)$. Alkylbenzenes ranged from 1 to $10 \%$ (Fig. 2c) with an average of $5 \pm 2 \%$ ( $1 \mathrm{SD}$ ). The highest proportions were in the coastal areas near to the Dmitry Laptev Strait (average 9\%), but not next to the Lena River mouth. The Kolyma River mouth sample, YS-34, also had high concentrations of alkylbenzenes $(9 \pm 1 \%)$. Furfurals ranged from 6 to $38 \%$ (Fig. 2d) with an average of $23 \pm 6 \%$ ( $1 \mathrm{SD}$ ). Their distribution does not show a clear pattern across the ESAS; large proportions of furfurals are found in both nearshore (TB-17, 37 $\pm 6 \%$ ) and offshore (YS-104, $37 \pm 3 \%$ ) sediments. Aromatics ranged from 3 to $17 \%$ (Fig. 2e) with an average of $9 \pm 4 \%$ (1 SD). They were most concentrated in the area between the Yana and Indigirka rivers, comprising the Dmitry Laptev Strait and the coastal area to the east of this (YS-22, YS-24, YS-26, YS-28; average: $16 \%$ ). Proportions were lowest in the far offshore samples (YS-88, YS-99, YS-100; average 4\%). Cyclopentenones ranged from 0 to $3 \%$ (Fig. 2f) with an average of $1 \pm 1 \%$ (1 SD). Concentrations were highest in the western nearshore areas, close to the Lena River, in the Buor-Khaya Bay and in the Dmitry Laptev Strait. Proportions on the offshore Arctic shelf were negligible.

\subsection{Regional variations in py-GCMS target compounds}

Terrestrial ICD samples were dominated by phenols, furfurals and pyridines, averaging 37, 25 and $23 \%$ respectively. Samples from the Kolyma River (code "CH") were richest in phenols, up to $47 \%$. There was not much difference between shallow, middle and deep samples. The nearshore Laptev Sea samples were dominated by phenols and furfurals, averaging 42 and $23 \%$ respectively. Phenols proportions were highest close to the rapidly eroding Muostakh Island (YS-15, YS-17) and next to the Lena River mouth (TB-46) with proportions dropping further from the shoreline down to just $17 \%$ at site TB-17. Pyridines proportions were low, just $15 \%$ on average. Cyclopentenones proportions, at 1-3\%, were the highest of any region. The Lena River mouth samples (TB-46, TB-59) were highest in cyclopentenones. The Dmitry Laptev Strait samples were dominated by phenols (46 and $52 \%$ ) but low in pyridines (14 and $17 \%$ ). The proportion of aromatics was higher than average (13 and 16\%), as was the proportion of cyclopentenones (1 and $3 \%$ ). Sample YS-24 also reported the lowest proportion of furfurals of all samples $(6 \%)$. The nearshore East Siberian Sea region had a decreasing amount of phenols in an offshore direction (51 down to $6 \%$ ) and an increasing amount of pyridines (16 up to $61 \%$ ). The two samples away from the river outflows (YS-26 and YS-31) were relatively low in furfurals (15 and $18 \%$ respectively) but high in alkylbenzenes (7 and 9\%) and relatively high in aromatics (16 and $15 \%$ ). The offshore Arctic shelf region contained few phenols (average $12 \%$ ) and was dominated by pyridines (average $55 \%$ ). Other compounds that were relatively enriched closer to shore were also reduced here (aromatics: 6\%; alkylbenzenes: 3\%; cyclopentenones: 0-1\%), but furfurals represent $24 \%$ of the material studied. The area furthest offshore to the east of the sample area (YS-88 and YS-100) was the most dominated by pyridines (74 and $69 \%$ respectively) and the most reduced in the other compounds (e.g. phenols: $3 \%$; aromatics: $3 \%$ ).

\section{Discussion}

\subsection{Deposition of old carbon on the ESAS}

The ${ }^{14} \mathrm{C}_{\mathrm{OC}}$ results confirm observations that the ESAS sediments are dominated by old carbon (Vonk et al., 2012). The additional data collected in this study allow a comprehensive map of radiocarbon ages across the ESAS to be produced (Fig. 4c). This shows that the oldest radiocarbon ages were measured in sediments from the Dmitry Laptev Strait region, whilst the youngest are found in the offshore Arctic shelf group, especially in the eastern East Siberian Sea. Even the youngest samples have quite negative $\Delta^{14} \mathrm{C}_{\mathrm{OC}}$ values, lower than $-350 \%$. This has been interpreted as a large input of old carbon from ICD permafrost deposits, especially via coastal erosion. Very negative $\Delta^{14} \mathrm{C}_{\mathrm{OC}}$ values in the Dmitry Laptev Strait zone support this theory, since it is a region of high coastal erosion rates (see Fig. 1; Lantuit et al., 2011), low fluvial input and low marine productivity (Sparkes et al., 2015).

\subsection{Distribution of compounds along a river-shelf transect}

To investigate offshore trends in the macromolecular groups, and to explore the relationships between them, sediments collected along a river-shelf transect from the outflow of the Kolyma River to the distal shelf were used as a case study. These sediments were ICD sample $\mathrm{CH}$ (average values from top, middle and lower samples), YS-34, YS-35, YS36, YS-37, YS-38, YS-39, YS-40, YS-41 and YS-90 (see Fig. 1). All transect sediment samples were dominated by furfurals, phenols and pyridines, which combined comprised $75 \%$ (YS-37) to $90 \%$ (YS-90) of the total abundance. In an off-shore direction, the relative phenol abundance decreased from $50 \%$ (at YS-34) to $11 \%$ (at YS-90, Fig. S2b). Phenols 


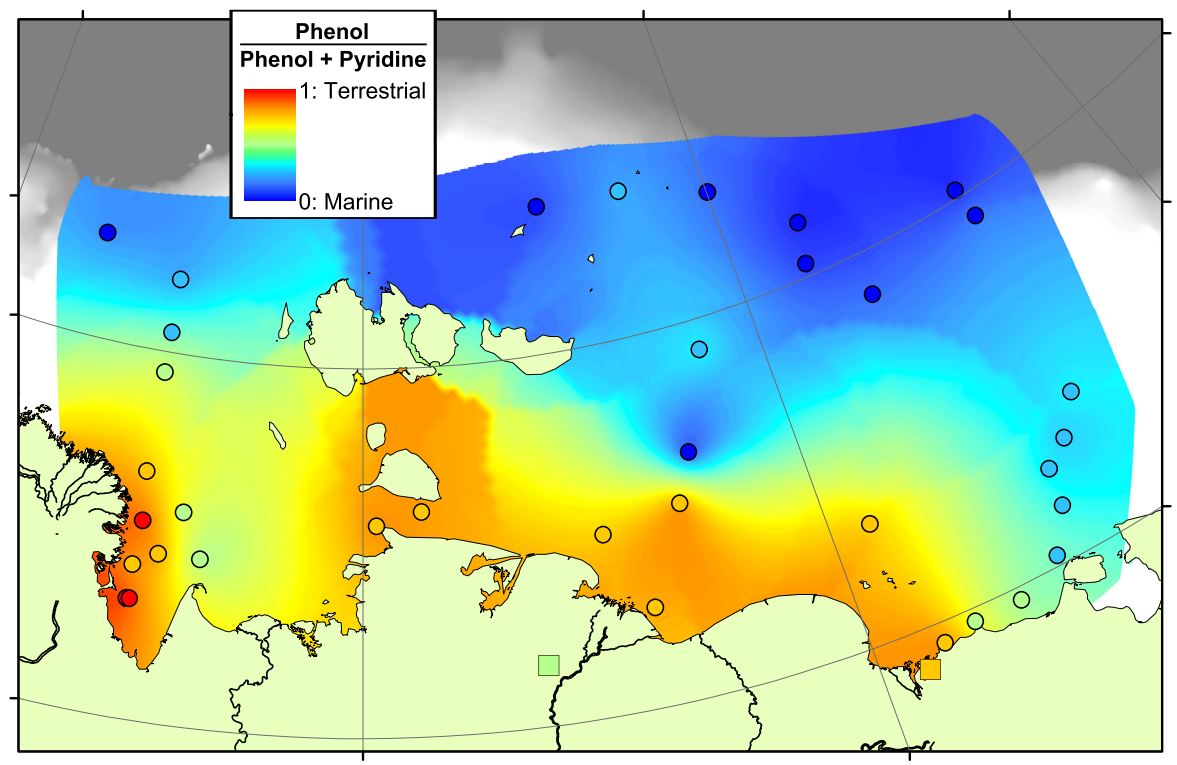

Figure 3. Map of the phenol / pyridine ratio across the ESAS (ratio is calculated from the relative abundances of phenol / (phenol + pyridine); higher values are interpreted as being terrestrial-dominated). Coloured circles show the ratio measured in each offshore sample; squares show onshore ice complex sample values. Interpolation between samples was carried out using a kriging algorithm within the software package ArcGIS.

can have multiple terrestrial (lignin, tannins and proteins; van Bergen et al., 1998) or marine origins (algal polyphenols; van Heemst et al., 1999). However, a strong correlation with lignin concentrations, determined in the same sediments using the $\mathrm{CuO}$ oxidation method $\left(r^{2}=0.98, p<0.01\right.$, $n=9$; Fig. S2b; Tesi et al., 2014), suggests that the phenols in both the transect sediments and the ESAS as a whole $\left(r^{2}=0.67, p<0.01, n=24\right.$; Fig. 4a) are primarily ligninderived. According to Tesi et al. (2016), plant material in these sediments is associated with large particles that deposit rapidly nearshore; OC from these particles forms a very minor component of the offshore sediment. Phenol abundance was $11 \%$ in the sediment collected at offshore station YS-90 and only $3 \%$ at nearby station YS- 88 , suggesting that terrestrial lignin-bearing particles were mostly deposited or degraded before they reached this part of the distal shelf. It also suggests that marine production of phenols was minimal. There is a strong linear correlation between phenol abundance and $\delta^{13} \mathrm{C}_{\mathrm{OC}}\left(r^{2}=0.69, p<0.01, n=9\right.$; Fig. S2d $)$, reinforcing the idea that the major source of phenols was terrestrial plant material. However, the relationship is somewhat better represented as a logarithmic trend $\left(r^{2}=0.81\right)$ in which relative abundance of phenols diminishes faster than the bulk $\delta^{13} \mathrm{C}_{\mathrm{OC}}$ value in nearshore settings. This may be due to the higher concentration of lignin phenols in large particles which deposit closer to the shoreline than the sediment as a whole. However, it has been shown that lignin phenols are present in all size fractions across the ESAS (Tesi et al., 2016) and therefore are not just tracking large terrOCrich particles. The non-linear correlation with BIT values
(Doğrul Selver et al., 2015), and the high abundance of phenols within the ICD samples, suggests that this is not due to phenols being dominantly river-derived material as has been suggested for branched GDGT biomarkers (Sparkes et al., 2015).

Pyridines abundance increased from 16 to $64 \%$ in an offshore direction along the same transect (Fig. S2a) and dominated the sediment collected at station YS-90 (64\%). The increasing pyridines abundance coincides with a shift towards more marine $\delta^{15} \mathrm{~N}$ values $\left(r^{2}=0.75, p<0.01, n=9\right.$; Fig. S2c) and $\delta^{13} \mathrm{C}_{\mathrm{OC}}\left(r^{2}=0.93, p<0.01, n=9\right.$; Fig. S2d). Although pyridines were present in ICD samples $(23 \%$, comparable to the $16 \%$ found in the nearshore samples), these results suggest that in the ESAS sediments, particularly those further offshore, they were mainly of marine origin and that the low-phenol, high-pyridine pattern observed in the furthest offshore sediments could potentially be used as a marine endmember composition. Pyridines themselves are not a marker for marine OC since they are present in onshore samples, with plant proteins being a likely terrestrial source.

\subsection{Distribution of phenols and pyridines across ESAS}

The patterns seen along the Kolyma River-distal shelf transect suggest that the distribution of phenols and pyridines in sediments may be usable as a proxy for measuring the relative input of terrestrial and marine carbon. There are several existing methods of performing this measurement, which can be used to test the applicability of the new py-GCMS-based 

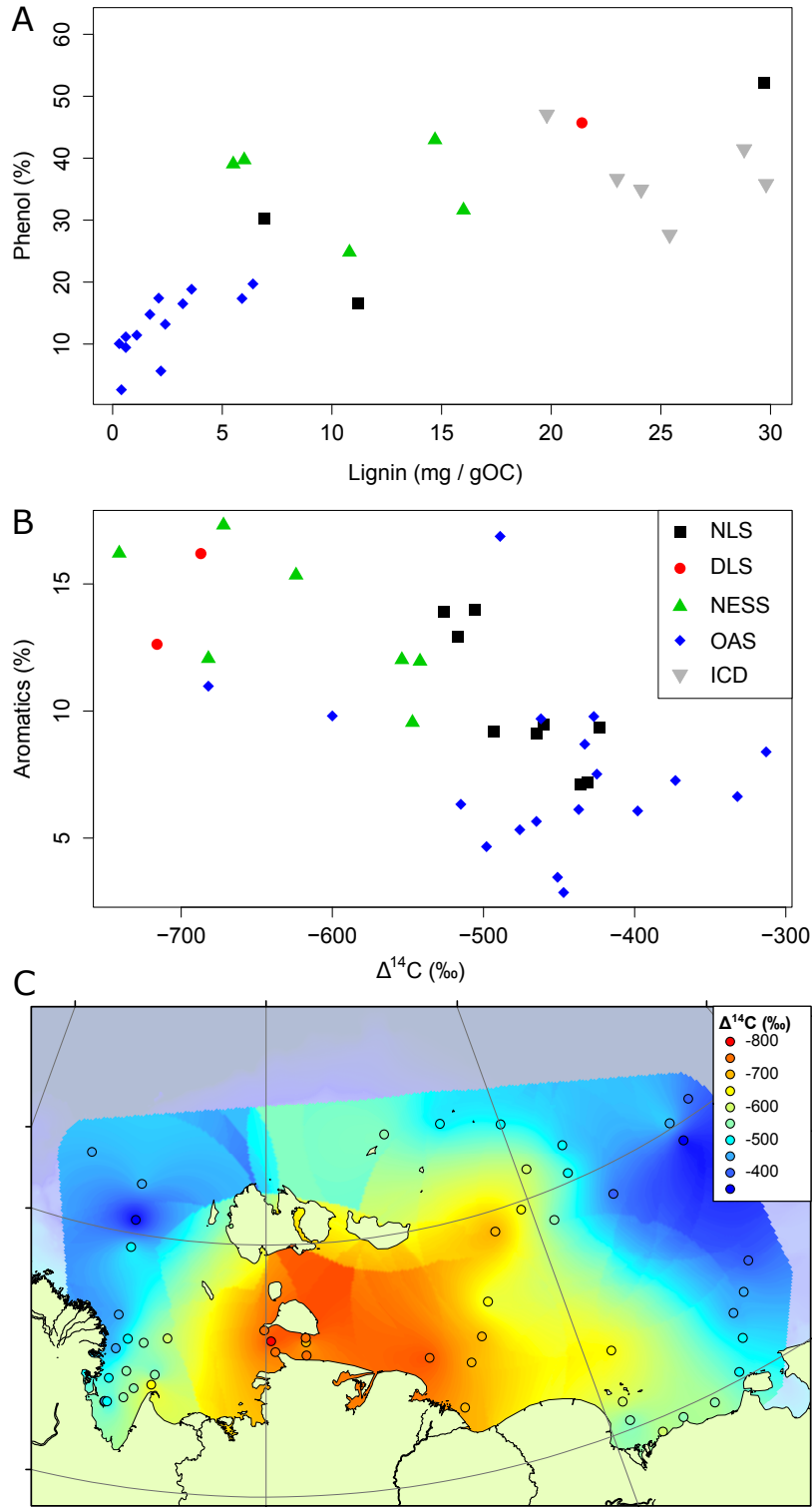

Figure 4. Correlation plots of (a) relative abundance of phenols vs. measured concentration of lignin phenols in identical samples as measured by Tesi et al. (2014) and (b) relative abundance of aromatics vs. $\Delta^{14} \mathrm{C}_{\mathrm{OC}}$ measurements from this study and Vonk et al. (2012). In each case, samples are distinguished by sample area (see legend; sample areas defined in Fig. 1). (c) Map of radiocarbon $\left(\Delta^{14} \mathrm{C}_{\mathrm{OC}}\right)$ values measured in this study and Vonk et al. (2012). Interpolation of $\Delta^{14} \mathrm{C}_{\mathrm{OC}}$ data was performed using a kriging algorithm within the software package ArcGIS. (DLS: Dmitry Laptev Strait; NLS: nearshore Laptev Sea; NESS: nearshore East Siberian Sea; OAS: offshore Arctic shelf).

approach. An index value, ranging from 0 to 1 , can be obtained by comparing the relative peak areas of phenols and pyridines (NB: this index is not affected by changes in any other compounds):

$$
\frac{\text { phenols }}{\text { phenols }+ \text { pyridines }} \text {. }
$$

In this index, a value of 1 means phenols dominated and is therefore interpreted as terrestrial in origin, and a value of 0 means pyridines dominated, interpreted as marine in origin. Our expansive dataset allows the phenols / pyridines ratio index (PPRI) to be examined as a proxy for terrOC across the entire ESAS. Figure 3 shows that the PPRI is highest in the nearshore Laptev Sea (0.88), next to the coastline and the Lena River mouth, and is fairly high in all coastal settings west of the Kolyma River. This includes areas that have been described as river-dominated and coastal-erosion-dominated in biomarker studies (Bischoff et al., 2016; Sparkes et al., 2015). The value drops towards 0 in distal offshore settings and east of the Kolyma River. In the western sections of the study area, off the Lena and Indigirka rivers, the transition from phenols-rich to pyridines-rich sediments occurs at about $200 \mathrm{~km}$ offshore. Off the Kolyma River this transition happens closer to shore. This pattern may be due to the enhanced export of lignin-derived phenol from the Lena River, due to its greater annual discharge (4.3 times more water, twice as much sediment; Gordeev, 2006) and less permafrost basin area ( $71 \%$ continuous permafrost in the Lena catchment compared to $99 \%$ for the Kolyma; Kotlyakov and Khromova, 2002). This would lead to a greater amount of terrestrial material (from the active layer at the top of the permafrost in both catchments, and also some deeper permafrost soil regions in the Lena catchment) being discharged from the Lena than the Kolyma. Alternatively, there could be an increased proportion of pyridines in the sediments off the Kolyma River due to the influx of marine OC-rich Pacific Ocean water through the Bering Strait (Semiletov et al., 2005; Bröder et al., 2016).

The PPRI can be compared to other terrestrial vs. marine proxy measurements in the region, namely the BIT index (Hopmans et al., 2004; Sparkes et al., 2015), $R^{\prime}$ soil proxy (Bischoff et al., 2016; Doğrul Selver et al., 2012) and $\delta^{13} \mathrm{C}_{\mathrm{OC}}$ (Vonk et al., 2012). Figure 5 shows the strong relationship between the phenol/pyridine ratio and these alternative proxies. There is very strong positive correlation with $R_{\text {soil }}^{\prime}\left(r^{2}=0.80, p<0.01, n=38\right)$ and very strong negative correlation with $\delta^{13} \mathrm{C}_{\mathrm{OC}}\left(r^{2}=0.74, p<0.01, n=34\right)$. There is also a significant correlation with BIT when analysed for a linear fit $\left(r^{2}=0.73, p<0.01, n=38\right)$. However, Fig. 5a shows that this relationship is likely non-linear in reality. The nearshore Laptev Sea, Dmitry Laptev Strait and nearshore East Siberian Sea samples show a fast reduction in BIT relative to PPRI, whilst offshore Arctic shelf samples have a range of PPRI values but uniformly low BIT. This relationship between BIT and PPRI is likely due to the biomarker sourcing and distribution patterns across the ESAS. Branched GDGT-rich river sediment deposits rapidly close to river mouths, whilst phenols, despite also depositing 

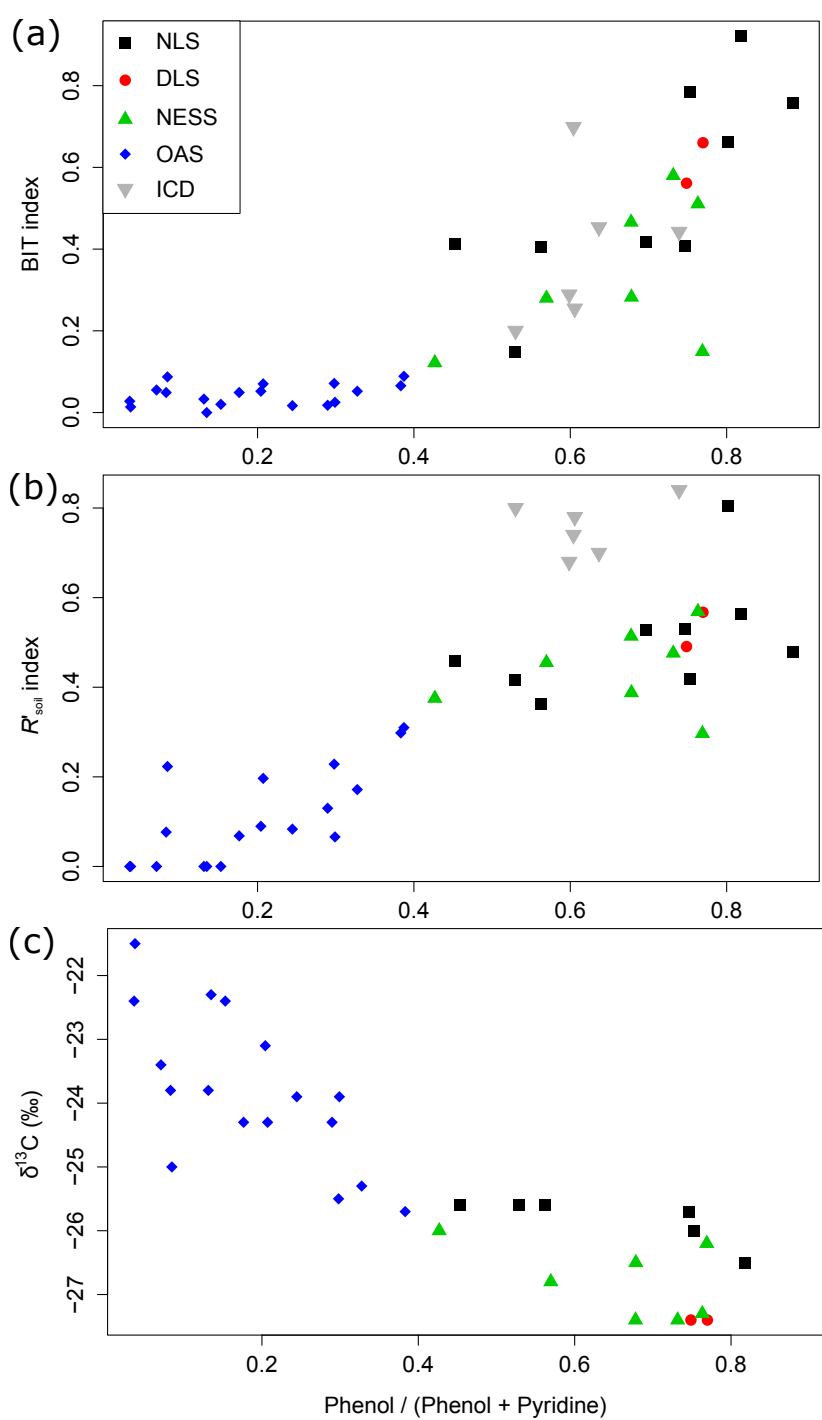

Figure 5. The phenol/pyridine ratio plotted against (a) BIT, (b) $R^{\prime}$ soil and (c) $\delta^{13} \mathrm{C}_{\mathrm{OC}}$. In each case there is a strong correlation between the proxies. (DLS: Dmitry Laptev Strait; NLS: nearshore Laptev Sea; NESS: nearshore East Siberian Sea; OAS: offshore Arctic shelf).

rapidly nearshore, are sourced from both rivers and coastlines (see model in Sparkes et al., 2015). Whilst it must be recognised that the Py-GCMS method described here is limited to dealing only with relative proportions of each compound group, the strength of these correlations with other terrestrial-marine proxies suggests that the PPRI is a useful tool for measuring the source of macromolecular organic carbon in a sediment. As the results are relative measurements, an increase in one compound class could represent either an enrichment in this group of molecules, or a decreased concentration of the other compound classes. Hydrodynamic sorting of particulate matter, rather than selective production or degradation, may produce changes in relative concentra- tion (Tesi et al., 2016). Despite these reservations, the PyGCMS approach has the advantage that it samples the nonextractable portion of the organic matter, whereas biomarker studies concentrate on the smaller extractable portion. Further examination of the phenol / pyridine ratio, particularly in other laboratories or with other pyrolysis equipment, should be undertaken to test the widespread applicability of the ratio as a geochemical tool.

\subsection{Furfurals and other compounds}

Unlike phenols and pyridines, and despite their relative abundance ranging from 6 to $38 \%$, there were no consistent nearshore-offshore patterns in the distribution of furfurals across the ESAS (Fig. 2d). One possible explanation for this observation is that furfurals may be representing the pyrolysis products of carbohydrates from both terrestrial and marine organic matter. Previous studies have suggested that there is a transition from terrestrial to marine domination of OC across the shelf, both for bulk OC (Semiletov et al., 2005; Vonk et al., 2012) and molecular biomarkers (Karlsson et al., 2011; Sparkes et al., 2015; Vonk et al., 2010, 2014). Therefore, it is expected that common compounds present in both terrestrial and marine organic matter, such as carbohydrates, may not show a distinctive change in relative concentration from nearshore to offshore. Simple measurement of furfurals may not show the transition from terrestrial to marine carbohydrate sources.

The across-shelf pattern of the minor compounds (aromatics, alkylbenzenes and cyclopentenones) suggests that the sources of these may not be identical. For example, aromatics are proportionally higher in regions far from the major river mouths (Dmitry Laptev Strait stations YS-22 and YS-24), in areas which are dominated by coastal erosion (Vonk et al., 2012) and near the Indigirka River (stations YS-26 and YS-28). In both of these areas, the proportion of pyridines was low, but there was no correlation with other compound classes. Both phenols and cyclopentenones were high in the Dmitry Laptev Strait and low off the Indigirka River; alkylbenzenes were high in the Dmitry Laptev Strait and at YS-26 but low at YS-28; furfurals were low in the Dmitry Laptev Strait and high off the Indigirka River. This suggests that the delivery mechanism (i.e. fluvial vs. coastal erosion) or offshore behaviour of aromatics is unlike that of the other compound classes. A comparison with radiocarbon data (Vonk et al., 2012) suggests that aromatics may be tracing the input of ancient terrOC to the ESAS. ${ }^{14} \mathrm{C}_{\mathrm{OC}}$ data from this and previous studies are mapped across the ESAS in Fig. $4 \mathrm{c}$ and bear a striking resemblance to the distribution of aromatics (Fig. 2e). Figure 4b shows a negative correlation between relative proportion of aromatics and $\Delta^{14} \mathrm{C}_{\mathrm{OC}}$ $\left(r^{2}=0.44, p<0.01, n=36\right)$. Note that there is weak or no correlation with other compound groups $\left(r^{2}\right.$ values: furfurals, 0.02; alkylbenzenes, 0.20; phenols, 0.13 ; cyclopentenones, 0.01 ; pyridines, 0.18 ). ICDs are much older than flu- 
vially eroded topsoil or marine productivity, with very little to no radiocarbon present $\left({ }^{14} \mathrm{C}_{\mathrm{OC}}=-940 \pm 84 \%, n=300\right.$; Vonk et al., 2012), and so areas dominated by coastal erosion rather than fluvial erosion have more negative ${ }^{14} \mathrm{C}_{\mathrm{OC}}$ values. In the ESAS sediments this corresponds to the Dmitry Laptev Strait and nearshore East Siberian Sea groups of samples. The youngest samples, with the least negative ${ }^{14} \mathrm{C}_{\mathrm{OC}}$, are those from the offshore Arctic shelf group with the lowest proportion of aromatics, thought to be dominated by marine productivity. The BKB samples, highly influenced by river erosion of soils (Sparkes et al., 2015), also have relatively young radiocarbon ages and lower proportions of aromatics. This correlation between older OC and aromatic compounds may be due to maturation of permafrost over time into simpler structures, especially into aromatic ones (Barden et al., 2011), and the protection of these compounds on mineral surfaces. Studies of soils from along an age gradient found that aromatic compounds were more likely to form mineral-organic associations more resistant to biodegradation (Mikutta et al., 2007, 2009). ICD samples were not enriched in aromatics, so the source of these aromatics is likely to be permafrost soil rather than ice complexes. The potential for pyrolysis-derived aromatic compounds being a tracer for very old permafrost material, especially coastal-erosion derived terrOC, should be investigated in future using more detailed sampling and compound-specific radiocarbon analysis. This would confirm the radiocarbon age of the aromatic compounds, as well as the mechanisms for their production and release.

\subsection{Principal component analysis}

The changing proportions of each compound class and a variety of proxy measurements (Bischoff et al., 2016; Sparkes et al., 2015; Vonk et al., 2012) were investigated by principal component analysis (PCA) using the software package "R". Principal components were calculated using the prcomp() function, which is a singular value decomposition method. Variables were automatically scaled and centred before analysis. Figure 6a shows the results of this analysis when performed on the py-GCMS compound classes. Principal component 1 , accounting for $58 \%$ of the variance, shows that the relative proportions of alkylbenzenes, aromatics, phenols and cyclopentenones are in opposition to the relative proportion of pyridines. This pattern can be broadly seen in Fig. 2, where the relative proportion of pyridines is highest where the other four are lowest, and vice versa. This variance is interpreted as the difference between terrestrial and marine OC-dominated sediments. A division of the PCA diagram at $x=0$ shows that all offshore Arctic shelf samples lie on the pyridines-dominated side of the chart and that all bar two of the nearshore Laptev Sea, Dmitry Laptev Strait, nearshore East Siberian Sea and ICD samples lie on the "terrestrial" side of the chart. Nearly orthogonal to these measurements is the proportion of furfurals, which is the main variable of principal component 2 (18\% of the variance). There are offshore Arctic shelf, nearshore Laptev Sea and nearshore East Siberian Sea sediments that are enriched in furfurals. This shows that the relative concentration of furfurals is not linked to the terrestrial-marine transition observed across the ESAS.

Figure $6 \mathrm{~b}$ shows the results of principal component analysis carried out on the various terrestrial vs. marine proxies discussed in this paper (PPRI, BIT index, $R_{\text {soil }}^{\prime}$ index and $\delta^{13} \mathrm{C}_{\mathrm{OC}}$ ) and $\Delta^{14} \mathrm{C}_{\mathrm{OC}}$. Principal component 1 , accounting for $80 \%$ of the variance, has $\delta^{13} \mathrm{C}_{\mathrm{OC}}$ in opposition to PPRI, BIT and $R^{\prime}$ soil. These four terrestrial vs. marine proxies are oriented opposite to $\delta^{13} \mathrm{C}_{\mathrm{OC}}$ in Fig. $6 \mathrm{~b}$ since the latter becomes more negative with increasing terrestrial material, whereas the other proxies trend to higher values with increased terrOC. Therefore $\mathrm{PC} 1$ denotes the transition from terrestrial to marine dominance of the OC. It is notable that BIT lies slightly away from the PPRI, $R_{\text {soil }}^{\prime}$ index and $\delta^{13} \mathrm{C}_{\mathrm{OC}}$ vectors. We interpret this as being due to the BIT index being strongly linked to river-derived terrOC in this region (Sparkes et al., 2015), whereas $\delta^{13} \mathrm{C}_{\mathrm{OC}}$ is measuring the entire sediment sample, and $R_{\text {soil }}^{\prime}$ is thought to measure both river and coastally derived terrOC (Bischoff et al., 2016). This offset is seen in the sample groups - the samples from the nearshore Laptev Sea, especially those near to the Lena River, plot close to the BIT vector, whilst the coastalerosion-dominated Dmitry Laptev Strait sample, along with the nearshore East Siberian Sea samples, plot further from the BIT vector. The $\Delta^{14} \mathrm{C}_{\mathrm{OC}}$ vector is at $45^{\circ}$ to the trend in terrestrial-marine proxies. This is interpreted as showing that all marine $\mathrm{OC}$ is dominated by young $\mathrm{OC}$ (high $\Delta^{14} \mathrm{C}_{\mathrm{OC}}$ values), as is material coming from the rivers. Coastal erosion sediments contain older material and therefore plot opposite to the $\Delta^{14} \mathrm{C}_{\mathrm{OC}}$ vector.

Therefore we can define three areas on the PCA diagram (Fig. 6b). As mentioned, PC1 divides the diagram into terrestrial and marine sections. Within the terrestrial half of the diagram, PC2 differentiates between river-derived and coastalerosion-derived terrOC. Following the offshore trends of each major river (shown in Fig. 6b), there is a transition from river-influenced terrOC to ICD-influenced terrOC and finally marine OC-dominated compositions. The Lena River is the most river-influenced trend, followed by the Kolyma River, with the Indigirka River offshore transect mostly dominated by terrOC from ice complexes. The Indigirka River sits between two areas of extremely high coastal erosion rates (Lantuit et al., 2011), so this is not unexpected. These patterns agree with the model published in Sparkes et al. (2015), which predicted a transition from river-derived upper permafrost to coastal-erosion-sourced ICD material to marine $\mathrm{OC}$ with distance offshore. Overall, principal component analysis has proven to be a valuable tool for understanding the transition between OC types across the ESAS. Multiple organic proxies agree that there is a large amount of terrestrial OC on the ESAS and that erosion of coastal sediments 

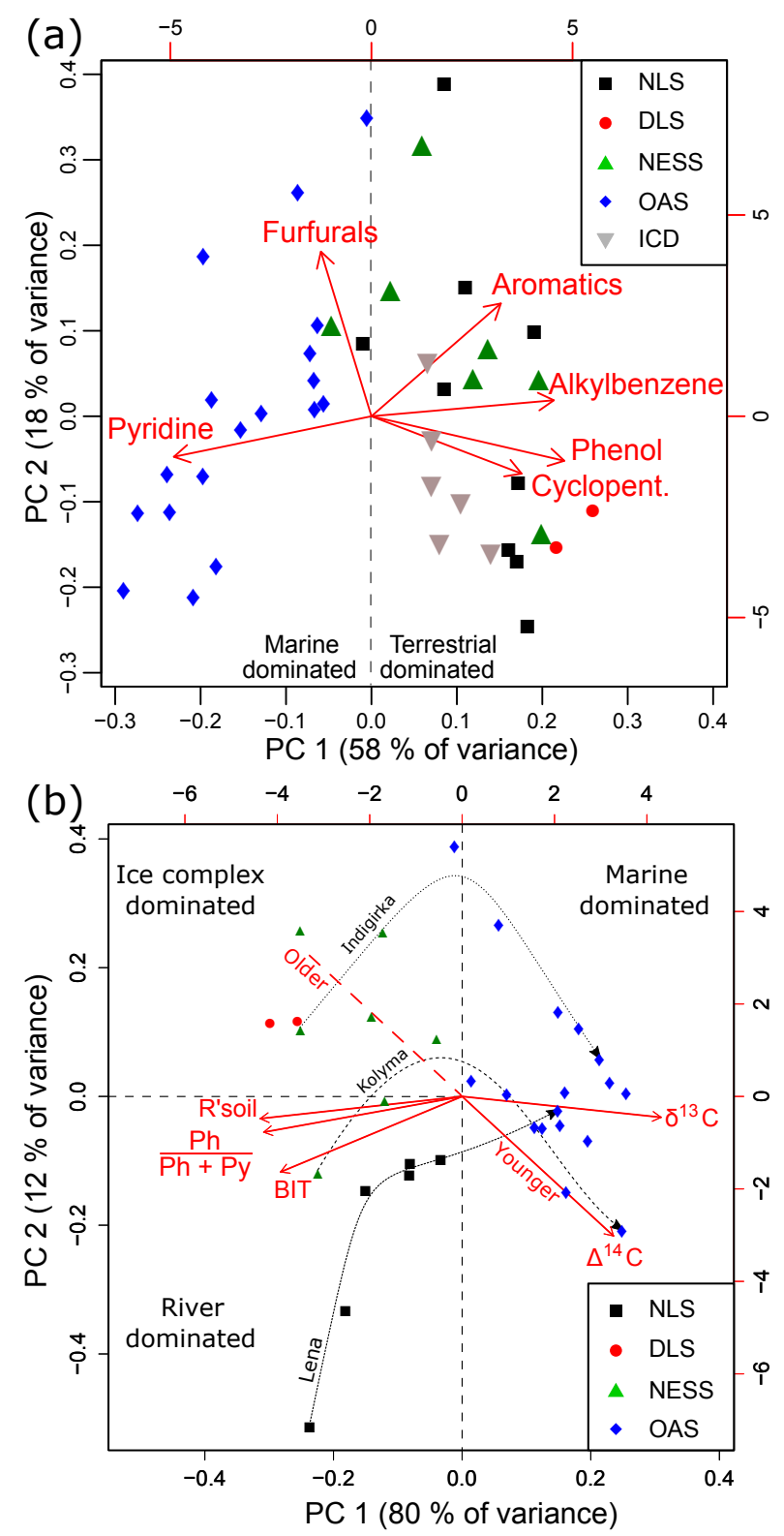

greatly increases the delivery and burial of terrestrial OC as compared to purely river-derived material.

\section{Conclusions}

By analysing sediment samples from across the East Siberian Arctic Shelf using the relatively rapid py-GCMS technique and categorising major pyrolysis moieties into a number of source-related classes, clear offshore trends were observed. Analyses indicated that nearshore samples were rich in phenols, aromatics, alkylbenzenes and cyclopentenones, which all decreased in importance offshore, suggesting a terrestrial source. Relative abundance of pyridines increased offshore, suggesting a marine source, whilst furfurals were present everywhere and may have been sourced from both terrestrial and marine carbohydrates. We propose that comparing the relative abundance of phenols to the sum of phenols and pyridines (phenol/pyridine ratio index) is a novel, useful tool for estimating the input of terrestrial and marine macromolecular OC in offshore sediments. Both a sub-sample set from the Kolyma River and sediments from across the entire ESAS show, for the first time, a strong correlation between the py-GCMS results (both relative values and the phenol / pyridine ratio) and previous, independent measurements of offshore terrOC (BIT index, $R^{\prime}$ soil index, lignin phenols). Principal component analysis, carried out on a large number of different measurements performed on these sediments, showed the offshore trend from river- and coastal-erosionderived material to marine OC across the ESAS and demonstrates the value of a holistic, multi-proxy approach to understanding the carbon cycle in complex environments.

\section{Data availability}

Data presented in this paper are included in the Supplement (Tables S2, S3). Raw radiocarbon data are available as Table $\mathrm{S} 4$.

\section{The Supplement related to this article is available online at doi:10.5194/tc-10-2485-2016-supplement.}

Figure 6. Principal component analyses of (a) various measured compounds from py-GCMS analysis (see Fig. 2 and Table S2) and (b) various terrestrial-marine proxies. Sample location regions are represented by symbol shapes and colours (see legend). Inferred domains of marine and terrestrial (split into river and ICD sections in panel b) dominance are shown with straight dashed lines. Offshore transects of surface sediments from major rivers to the ESAS (panel b) are shown using curved dotted lines and labelled with the river name at the nearshore end of the offshore transect. (DLS: Dmitry Laptev Strait; NLS: nearshore Laptev Sea; NESS: nearshore East Siberian Sea; OAS: offshore Arctic shelf).

Author contributions. Ö. Gustafsson, B. E. van Dongen and I. P. Semiletov collected samples along with the crew of ISSS-08. H. M. Talbot and B. E. van Dongen designed the study. Py-GCMS measurements were carried out by R. B. Sparkes and A. Doğrul Selver. $\Delta^{14} \mathrm{C}$ measurements were carried out by $\mathrm{N}$. Haghipour, L. Wacker and T. I. Eglinton. R. B. Sparkes, A. Doğrul Selver, H. M. Talbot and B. E. van Dongen prepared the manuscript with contributions from all co-authors. 
Acknowledgements. We gratefully acknowledge receipt of a NERC research grant (NE/I024798/1 and NE/I027967/1) to B. E. van Dongen and H. M. Talbot., a PhD studentship to A. Doğrul Selver funded by the Ministry of National Education of Turkey, and support from the Government of the Russian Federation (mega-grant 14.Z50.31.0012) to I. Semiletov. We thank the crew and personnel of the R/V YakobSmirnitskyi and all colleagues in the International Siberian Shelf Study (ISSS) programme for support, including sampling. We thank T. Tesi for providing the Yedoma samples for the Kolyma and Indigirka catchment areas. The ISSS programme is supported by the Knut and Alice Wallenberg Foundation, the Far Eastern Branch of the Russian Academy of Sciences, the Swedish Research Council (VR contract nos. 621-2004-4039, 621-2007-4631 and 621-2013-5297), the US National Oceanic and Atmospheric Administration (OAR Climate Program Office, NA08OAR4600758/Siberian Shelf Study), the Russian Foundation of Basic Research (08-05-13572, 08-05-00191-a and 07-05-00050a), the Swedish Polar Research Secretariat, the Nordic Council of Ministers and the US National Science Foundation (OPP ARC 0909546). Finally, we thank the associate editor and two anonymous reviewers for their positive comments and suggestions.

Edited by: N. Kirchner

Reviewed by: two anonymous referees

\section{References}

Alling, V., Sanchez-Garcia, L., Porcelli, D., Pugach, S., Vonk, J. E., van Dongen, B., M orth, C.-M., Anderson, L. G., Sokolov, A., Andersson, P., Humborg, C., Semiletov, I., and Gustafsson, Ö.: Nonconservative behavior of dissolved organic carbon across the Laptev and East Siberian seas, Global Biogeochem. Cy., 24, GB4033, doi:10.1029/2010GB003834, 2010.

Anderson, L. G., Jutterström, S., Hjalmarsson, S., Wåhlström, I., and Semiletov, I. P.: Out-gassing of $\mathrm{CO}_{2}$ from Siberian Shelf seas by terrestrial organic matter decomposition, Geophys. Res. Lett., 36, L20601, doi:10.1029/2009GL040046, 2009.

Barden, H. E., Wogelius, R. A., Li, D., Manning, P. L., Edwards, N. P., and van Dongen, B. E.: Morphological and Geochemical Evidence of Eumelanin Preservation in the Feathers of the Early Cretaceous Bird, Gansus yumenensis, PLoS ONE, 6, 1-9, doi:10.1371/journal.pone.0025494, 2011.

Belicka, L. L. and Harvey, H. R.: The sequestration of terrestrial organic carbon in Arctic Ocean sediments: A comparison of methods and implications for regional carbon budgets, Geochim. Cosmochim. Ac., 73, 6231-6248, doi:10.1016/j.gca.2009.07.020, 2009.

Bischoff, J., Sparkes, R. B., Dogrul Selver, A., Spencer, R. G. M., Gustafsson, Ö., Semiletov, I. P., Dudarev, O. V., Wagner, D., Rivkina, E., van Dongen, B. E., and Talbot, H. M.: Source, transport and fate of soil organic matter inferred from microbial biomarker lipids on the East Siberian Arctic Shelf, Biogeosciences, 13, 4899-4914, doi:10.5194/bg-13-4899-2016, 2016.

Bröder, L., Tesi, T., Andersson, A., Eglinton, T. I., Semiletov, I. P., Dudarev, O. V., Roos, P., and Gustafsson, Ö.: Historical records of organic matter supply and degradation sta- tus in the East Siberian Sea, Org. Geochem., 91, 16-30, doi:10.1016/j.orggeochem.2015.10.008, 2016.

Charkin, A. N., Dudarev, O. V., Semiletov, I. P., Kruhmalev, A. V., Vonk, J. E., Sánchez-García, L., Karlsson, E., and Gustafsson, Ö.: Seasonal and interannual variability of sedimentation and organic matter distribution in the Buor-Khaya Gulf: the primary recipient of input from Lena River and coastal erosion in the southeast Laptev Sea, Biogeosciences, 8, 2581-2594, doi:10.5194/bg8-2581-2011, 2011.

Doğrul Selver, A., Talbot, H. M., Gustafsson, Ö., Boult, S., and van Dongen, B. E.: Soil organic matter transport along an sub-Arctic river- sea transect, Org. Geochem., 51, 63-72, doi:10.1016/j.orggeochem.2012.08.002, 2012.

Doğrul Selver, A., Sparkes, R. B., Bischoff, J., Talbot, H. M., Gustafsson, Ö., Semiletov, I. P., Dudarev, O. V., Boult, S., and van Dongen, B. E.: Distributions of bacterial and archaeal membrane lipids in surface sediments reflect differences in input and loss of terrestrial organic carbon along a cross-shelf Arctic transect, Org. Geochem., 83, 16-26, doi:10.1016/j.orggeochem.2015.01.005, 2015.

Drenzek, N. J., Montluçon, D. B., Yunker, M. B., Macdonald, R. W., and Eglinton, T. I.: Constraints on the origin of sedimentary organic carbon in the Beaufort Sea from coupled molecular ${ }^{13} \mathrm{C}$ and ${ }^{14} \mathrm{C}$ measurements, Mar. Chem., 103, 146-162, doi:10.1016/j.marchem.2006.06.017, 2007.

Feng, X., Vonk, J. E., van Dongen, B. E., Gustafsson, Ö., Semiletov, I. P., Dudarev, O. V., Wang, Z., Montluçon, D. B., Wacker, L., and Eglinton, T. I.: Differential mobilization of terrestrial carbon pools in Eurasian Arctic river basins, P. Natl. Acad. Sci., 110, 14168-14173, doi:10.1073/pnas.1307031110, 2013.

Feng, X., Gustafsson, Ö., Holmes, R. M., Vonk, J. E., van Dongen, B. E., Semiletov, I. P., Dudarev, O. V., Yunker, M. B., Macdonald, R. W., Montluçon, D. B., and Eglinton, T. I.: Multi-molecular tracers of terrestrial carbon transfer across the pan-Arctic: comparison of hydrolyzable components with plant wax lipids and lignin phenols, Biogeosciences, 12, 4841-4860, doi:10.5194/bg12-4841-2015, $2015 \mathrm{a}$.

Feng, X., Gustafsson, Ö., Holmes, R. M., Vonk, J. E., van Dongen, B. E., Semiletov, I. P., Dudarev, O. V., Yunker, M. B., Macdonald, R. W., Wacker, L., Montluçon, D. B., and Eglinton, T. I.: Multimolecular tracers of terrestrial carbon transfer across the pan-Arctic: ${ }^{14} \mathrm{C}$ characteristics of sedimentary carbon components and their environmental controls, Global Biogeochem. Cy., 29, 1855-1873, doi:10.1002/2015GB005204, 2015GB005204, $2015 b$.

Fernandes, M. and Sicre, M.-A.: The importance of terrestrial organic carbon inputs on Kara Sea shelves as revealed by nalkanes, OC and $\delta^{13} \mathrm{C}$ values, Org. Geochem., 31, 363-374, doi:10.1016/S0146-6380(00)00006-1, 2000.

Gordeev, V. V.: Fluvial sediment flux to the Arctic Ocean, Geomorphology, 80, 94-104, doi:10.1016/j.geomorph.2005.09.008, 2006.

Guo, L., Semiletov, I., Gustafsson, Ö., Ingri, J., Andersson, P., Dudarev, O., and White, D.: Characterization of Siberian Arctic coastal sediments: Implications for terrestrial organic carbon export, Global Biogeochem. Cy., 18, GB1036, doi:10.1029/2003GB002087, 2004.

Guo, L., White, D. M., Xu, C., and Santschi, P. H.: Chemical and isotopic composition of high-molecular-weight dissolved or- 
ganic matter from the Mississippi River plume, Mar. Chem., 114, 63-71, doi:10.1016/j.marchem.2009.04.002, 2009.

Gustafsson, Ö., van Dongen, B. E., Vonk, J. E., Dudarev, O. V., and Semiletov, I. P.: Widespread release of old carbon across the Siberian Arctic echoed by its large rivers, Biogeosciences, 8, 1737-1743, doi:10.5194/bg-8-1737-2011, 2011.

Holmes, R. M., McClelland, J. W., Peterson, B. J., Shiklomanov, I. A., Shiklomanov, A. I., Zhulidov, A. V., Gordeev, V. V., and Bobrovitskaya, N. N.: A circumpolar perspective on fluvial sediment flux to the Arctic ocean, Global Biogeochem. Cy., 16, 1098, doi:10.1029/2001GB001849, 2002.

Holmes, R. M., Coe, M. T., Fiske, G. J., Gurtovaya, T., McClelland, J. W., Shiklomanov, A. I., Spencer, R. G. M., Tank, S. E., and Zhulidov, A. V.: Climate Change Impacts on the Hydrology and Biogeochemistry of Arctic Rivers, John Wiley \& Sons Ltd, 1-26, doi:10.1002/9781118470596.ch1, 2012.

Hopmans, E. C., Weijers, J. W. H., Schefuss, E., Herfort, L., Sinninghe Damsté, J. S., and Schouten, S.: A novel proxy for terrestrial organic matter in sediments based on branched and isoprenoid tetraether lipids, Earth Planet. Sc. Lett., 224, 107-116, doi:10.1016/j.eps1.2004.05.012, 2004.

IPCC: Climate Change 2013: The Physical Science Basis, in: Contribution of Working Group I to the Fifth Assessment Report of the Intergovernmental Panel on Climate Change, Tech. rep., 2013.

Karlsson, E. S., Charkin, A., Dudarev, O., Semiletov, I., Vonk, J. E., Sánchez-García, L., Andersson, A., and Gustafsson, Ö.: Carbon isotopes and lipid biomarker investigation of sources, transport and degradation of terrestrial organic matter in the Buor-Khaya Bay, SE Laptev Sea, Biogeosciences, 8, 1865-1879, doi:10.5194/bg-8-1865-2011, 2011.

Karlsson, E., Brüchert, V., Tesi, T., Charkin, A., Dudarev, O., Semiletov, I., and Gustafsson, Ö.: Contrasting regimes for organic matter degradation in the East Siberian Sea and the Laptev Sea assessed through microbial incubations and molecular markers, Mar. Chem., 170, 11-22, doi:10.1016/j.marchem.2014.12.005, 2015.

Komada, T., Anderson, M. R., and Dorfmeier, C. L.: Carbonate removal from coastal sediments for the determination of organic carbon and its isotopic signatures, $\delta^{13} \mathrm{C}$ and $\Delta^{14} \mathrm{C}$ : comparison of fumigation and direct acidification by hydrochloric acid, Limnol. Oceanogr.-Meth., 6, 254-262, doi:10.4319/lom.2008.6.254, 2008.

Kotlyakov, V. and Khromova, T.: Maps of Permafrost and Ground Ice, Version 1, in: Land Resources of Russia, National Snow and Ice Data Center, Boulder, 2002.

Lantuit, H., Overduin, P. P., Couture, N., Wetterich, S., Aré, F., Atkinson, D., Brown, J., Cherkashov, G., Drozdov, D., Forbes, D. L., Graves-Gaylord, A., Grigoriev, M., Hubberten, H.-W., Jordan, J., Jorgenson, T., Ødegård, R. S., Ogorodov, S., Pollard, W. H., Rachold, V., Sedenko, S., Solomon, S., Steenhuisen, F., Streletskaya, I., and Vasiliev, A.: The Arctic Coastal Dynamics Database: A New Classification Scheme and Statistics on Arctic Permafrost Coastlines, Estuar. Coast., 35, 383-400, doi:10.1007/s12237-010-9362-6, 2011.

Lantuit, H., Overduin, P. P., and Wetterich, S.: Recent Progress Regarding Permafrost Coasts, Permafrost Periglac., 24, 120-130, doi:10.1002/ppp.1777, 2013.
Mikutta, R., Mikutta, C., Kalbitz, K., Scheel, T., Kaiser, K., and Jahn, R.: Biodegradation of forest floor organic matter bound to minerals via different binding mechanisms, Geochim. Cosmochim. Ac., 71, 2569-2590, doi:10.1016/j.gca.2007.03.002, 2007.

Mikutta, R., Schaumann, G. E., Gildemeister, D., Bonneville, S., Kramer, M. G., Chorover, J., Chadwick, O. A., and Guggenberger, G.: Biogeochemistry of mineral-organic associations across a long-term mineralogical soil gradient (0.3-4100 kyr), Hawaiian Islands, Geochim. Cosmochim. Ac., 73, 2034-2060, doi:10.1016/j.gca.2008.12.028, 2009.

O’Donnell, J. A., Aiken, G. R., Walvoord, M. A., Raymond, P. A., Butler, K. D., Dornblaser, M. M., and Heckman, K.: Using dissolved organic matter age and composition to detect permafrost thaw in boreal watersheds of interior Alaska, J. Geophys. Res.-Biogeo., 119, 2155-2170, doi:10.1002/2014JG002695, 2014JG002695, 2014.

Peterson, B. J., Holmes, R. M., McClelland, J. W., Vörösmarty, C. J., Lammers, R. B., Shiklomanov, A. I., Shiklomanov, I. A., and Rahmstorf, S.: Increasing River Discharge to the Arctic Ocean, Science, 298, 2171-2173, doi:10.1126/science.1077445, 2002.

Peulvé, S., Sicre, M., Saliot, A., De Leeuw, J., and Baas, M.: Molecular characterization of suspended and sedimentary organic matter in an Arctic delta, Limnol. Oceanogr, 41, 488-497, doi:10.4319/lo.1996.41.3.0488, 1996.

Ping, C.-L., Michaelson, G. J., Guo, L., Jorgenson, M. T., Kanevskiy, M., Shur, Y., Dou, F., and Liang, J.: Soil carbon and material fluxes across the eroding Alaska Beaufort Sea coastline, J. Geophys. Res.-Biogeo., 116, G02004, doi:10.1029/2010JG001588, 2011.

Rachold, V., Eicken, H., Gordeev, V. V., Grigoriev, M. N., Hubberten, H. W., Lisitzin, A. P., Shevchenko, V. P., and Schirrmeister, L.: Modern Terrigenous Organic Carbon Input to the Arctic Ocean, Springer Berlin Heidelberg, 33-55, doi:10.1007/978-3642-18912-8_2, 2004.

Sánchez-García, L., Alling, V., Pugach, S., Vonk, J., van Dongen, B. E., Humborg, C., Dudarev, O., Semiletov, I., and Gustafsson, O.: Inventories and behavior of particulate organic carbon in the Laptev and East Siberian seas, Global Biogeochem. Cy., 25, GB2007, doi:10.1029/2010GB003862, 2011.

Sánchez-García, L., Vonk, J. E., Charkin, A. N., Kosmach, D., Dudarev, O. V., Semiletov, I. P., and Gustafsson, Ö.: Characterisation of Three Regimes of Collapsing Arctic Ice Complex Deposits on the SE Laptev Sea Coast using Biomarkers and Dual Carbon Isotopes, Permafrost Periglac., 25, 172-183, doi:10.1002/ppp.1815, 2014.

Schirrmeister, L., Kunitsky, V. V., Grosse, G., Kuznetsova, T. V., Derevyagin, A. Y., Wetterich, S., and Siegert, C.: The Yedoma Suite of the Northeastern Siberian Shelf Region Characteristics and Concept of Formation, in: Proceedings of the 9th International Conference on Permafrost, University of Alaska Fairbanks, edited by: Kane, D. L. and Hinkel, K. M., Institute of Northern Engineering, 1595-1601, 2008.

Schirrmeister, L., Kunitsky, V., Grosse, G., Wetterich, S., Meyer, H., Schwamborn, G., Babiy, O., Derevyagin, A., and Siegert, C.: Sedimentary characteristics and origin of the Late Pleistocene Ice Complex on north-east Siberian Arctic coastal 
lowlands and islands - A review, Quatern. Int., 241, 3-25, doi:10.1016/j.quaint.2010.04.004, 2011.

Schuur, E. A. G., Bockheim, J., Canadell, J. G., Euskirchen, E., Field, C. B., Goryachkin, S. V., Hagemann, S., Kuhry, P., Lafleur, P. M., Lee, H., Mazhitova, G., Nelson, F. E., Rinke, A., Romanovsky, V. E., Shiklomanov, N., Tarnocai, C., Venevsky, S., Vogel, J. G., and Zimov, S. A.: Vulnerability of Permafrost Carbon to Climate Change: Implications for the Global Carbon $\mathrm{Cy}$ cle, BioScience, 58, 701-714, doi:10.1641/B580807, 2008.

Schuur, E. A. G., McGuire, A. D., Schadel, C., Grosse, G., Harden, J. W., Hayes, D. J., Hugelius, G., Koven, C. D., Kuhry, P., Lawrence, D. M., Natali, S. M., Olefeldt, D., Romanovsky, V. E., Schaefer, K., Turetsky, M. R., Treat, C. C., and Vonk, J. E.: Climate change and the permafrost carbon feedback, Nature, 520, 171-179, doi:10.1038/nature14338, 2015.

Semiletov, I. and Gustafsson, Ö.: East Siberian Shelf Study Alleviates Scarcity of Observations, EOS T. Am. Geophys. Un., 90, 145-146, doi:10.1029/2009EO170001, 2009.

Semiletov, I., Dudarev, O., Luchin, V., Charkin, A., Shin, K.-H., and Tanaka, N.: The East Siberian Sea as a transition zone between Pacific-derived waters and Arctic shelf waters, Geophys. Res. Lett., 32, L10614, doi:10.1029/2005GL022490, 2005.

Semiletov, I., Pipko, I., Gustafsson, O., Anderson, L. G., Sergienko, V., Pugach, S., Dudarev, O., Charkin, A., Gukov, A., Broder, L., Andersson, A., Spivak, E., and Shakhova, N.: Acidification of East Siberian Arctic Shelf waters through addition of freshwater and terrestrial carbon, Nat. Geosci., 9, 361-365, doi:10.1038/ngeo2695, 2016

Semiletov, I. P., Pipko, I. I., Repina, I., and Shakhova, N. E.: Carbonate chemistry dynamics and carbon dioxide fluxes across the atmosphere-ice-water interfaces in the Arctic Ocean: Pacific sector of the Arctic, J. Marine Syst., 66, 204-226, doi:10.1016/j.jmarsys.2006.05.012, 2007.

Semiletov, I. P., Shakhova, N. E., Sergienko, V. I., Pipko, I. I., and Dudarev, O. V.: On carbon transport and fate in the East Siberian Arctic land- shelf- atmosphere system, Environ. Res. Lett., 7, 015201, doi:10.1088/1748-9326/7/1/015201, 2012.

Sparkes, R. B., Dogrul Selver, A., Bischoff, J., Talbot, H. M., Gustafsson, Ö., Semiletov, I. P., Dudarev, O. V., and van Dongen, B. E.: GDGT distributions on the East Siberian Arctic Shelf: implications for organic carbon export, burial and degradation, Biogeosciences, 12, 3753-3768, doi:10.5194/bg-12-3753-2015, 2015.

Stein, R. and MacDonald, R.: The Organic Carbon Cycle in the Arctic Ocean, Springer, Berlin, doi:10.1007/978-3-642-18912-8, 2004.

Stendel, M. and Christensen, J. H.: Impact of global warming on permafrost conditions in a coupled GCM, Geophys. Res. Lett., 29, 1632, doi:10.1029/2001GL014345, 2002.

Strauss, J., Schirrmeister, L., Wetterich, S., Borchers, A., and Davydov, S. P.: Grain-size properties and organic-carbon stock of Yedoma Ice Complex permafrost from the Kolyma lowland, northeastern Siberia, Global Biogeochem. Cy., 26, GB3003, doi:10.1029/2011GB004104, 2012.

Strauss, J., Schirrmeister, L., Grosse, G., Wetterich, S., Ulrich, M., Herzschuh, U., and Hubberten, H.-W.: The deep permafrost carbon pool of the Yedoma region in Siberia and Alaska, Geophys. Res. Lett., 40, 6165-6170, doi:10.1002/2013GL058088, 2013GL058088, 2013.
Tesi, T., Semiletov, I., Hugelius, G., Dudarev, O., Kuhry, P., and Gustafsson, Ö.: Composition and fate of terrigenous organic matter along the Arctic land-ocean continuum in East Siberia: Insights from biomarkers and carbon isotopes, Geochim. Cosmochim. Ac., 133, 235-256, doi:10.1016/j.gca.2014.02.045, 2014.

Tesi, T., Semiletov, I., Dudarev, O., Andersson, A., and Gustafsson, Ö.: Matrix association effects on hydrodynamic sorting and degradation of terrestrial organic matter during cross-shelf transport in the Laptev and East Siberian shelf seas, J. Geophys. Res.Biogeo., 121, 731-752, doi:10.1002/2015JG003067, 2016.

van Bergen, P. F., Nott, C. J., Bull, I. D., Poulton, P. R., and Evershed, R. P.: Organic geochemical studies of soils from the Rothamsted Classical Experiments- IV. Preliminary results from a study of the effect of soil $\mathrm{pH}$ on organic matter decay, Org. Geochem., 29, 1779-1795, doi:10.1016/S0146-6380(98)001880,1998 .

van Dongen, B. E., Semiletov, I., Weijers, J. W. H., and Gustafsson, Ö.: Contrasting lipid biomarker composition of terrestrial organic matter exported from across the Eurasian Arctic by the five great Russian Arctic rivers, Global Biogeochem Cy, 22, GB1011, doi:10.1029/2007GB002974, 2008a.

van Dongen, B. E., Zencak, Z., and Gustafsson, Ö.: Differential transport and degradation of bulk organic carbon and specific terrestrial biomarkers in the surface waters of a subarctic brackish bay mixing zone, Mar. Chem., 112, 203-214, doi:10.1016/j.marchem.2008.08.002, 2008b.

van Heemst, J. D. H., van Bergen, P. F., Stankiewicz, B. A., and de Leeuw, J. W.: Multiple sources of alkylphenols produced upon pyrolysis of DOM, POM and recent sediments, J. Anal. Appl. Pyrol., 52, 239-256, doi:10.1016/S0165-2370(99)00047-9, 1999.

Vonk, J. E. and Gustafsson, Ö.: Permafrost-carbon complexities, Nat. Geosci., 6, 675-676, doi:10.1038/ngeo1937, 2013.

Vonk, J. E., van Dongen, B. E., and Gustafsson, Ö.: Selective preservation of old organic carbon fluvially released from sub-Arctic soils, Geophys. Res. Lett., 37, L11605, doi:10.1029/2010GL042909, 2010.

Vonk, J. E., Sanchez-Garcia, L., van Dongen, B. E., Alling, V., Kosmach, D., Charkin, A., Semiletov, I. P., Dudarev, O. V., Shakhova, N., Roos, P., Eglinton, T. I., Andersson, A., and Gustafsson, Ö.: Activation of old carbon by erosion of coastal and subsea permafrost in Arctic Siberia, Nature, 489, 137-140, doi:10.1038/nature11392, 10.1038/nature11392, 2012.

Vonk, J. E., Mann, P. J., Davydov, S., Davydova, A., Spencer, R. G. M., Schade, J., Sobczak, W. V., Zimov, N., Zimov, S., Bulygina, E., Eglinton, T. I., and Holmes, R. M.: High biolability of ancient permafrost carbon upon thaw, Geophys. Res. Lett., 40, 2689-2693, doi:10.1002/grl.50348, 2013a.

Vonk, J. E., Mann, P. J., Dowdy, K. L., Davydova, A., Davydov, S. P., Zimov, N., Spencer, R. G. M., Bulygina, E. B., Eglinton, T. I., and Holmes, R. M.: Dissolved organic carbon loss from Yedoma permafrost amplified by ice wedge thaw, Environ. Res. Lett., 8, 035023, doi:10.1088/1748-9326/8/3/035023, 2013b.

Vonk, J. E., Semiletov, I. P., Dudarev, O. V., Eglinton, T. I., Andersson, A., Shakhova, N., Charkin, A., Heim, B., and Gustafsson, Ö.: Preferential burial of permafrost-derived organic carbon in Siberian-Arctic shelf waters, J. Geophys. Res.-Oceans, 119, 8410-8421, doi:10.1002/2014JC010261, 2014. 
Vonk, J. E., Tank, S. E., Bowden, W. B., Laurion, I., Vincent, W. F., Alekseychik, P., Amyot, M., Billet, M. F., Canário, J., Cory, R. M., Deshpande, B. N., Helbig, M., Jammet, M., Karlsson, J., Larouche, J., MacMillan, G., Rautio, M., Walter Anthony, K. M., and Wickland, K. P.: Reviews and syntheses: Effects of permafrost thaw on Arctic aquatic ecosystems, Biogeosciences, 12, 7129-7167, doi:10.5194/bg-12-7129-2015, 2015.

Winterfeld, M., Goñi, M. A., Just, J., Hefter, J., and Mollenhauer, G.: Characterization of particulate organic matter in the Lena River delta and adjacent nearshore zone, NE Siberia - Part 2: Lignin-derived phenol compositions, Biogeosciences, 12, 22612283, doi:10.5194/bg-12-2261-2015, 2015.

Xu, C., Guo, L., Dou, F., and Ping, C.-L.: Potential DOC production from size-fractionated Arctic tundra soils, Cold Reg. Sci. Technol., 55, 141-150, doi:10.1016/j.coldregions.2008.08.001, 2009.
Yunker, M. B., Macdonald, R. W., Veltkamp, D. J., and Cretney, W. J.: Terrestrial and marine biomarkers in a seasonally ice-covered Arctic estuary - integration of multivariate and biomarker approaches, Mar. Chem., 49, 1-50, doi:10.1016/03044203(94)00057-K, 1995.

Zimov, S. A., Davydov, S. P., Zimova, G. M., Davydova, A. I., Schuur, E. A. G., Dutta, K., and Chapin, F. S.: Permafrost carbon: Stock and decomposability of a globally significant carbon pool, Geophys. Res. Lett., 33, L20502, doi:10.1029/2006GL027484, 2006. 